\title{
Jejak Karbon Individu Pegawai di Instansi Pemerintah \\ Studi Kasus Pegawai Pemerintahan di Kawasan Puspiptek, Tangerang Selatan
}

\author{
Investigating the Personal Carbon Footprint of \\ a Staft Goverment Office \\ Case study on Goverment Staft at Puspiptek Area, Tangerang Selatan
}

\author{
ARIF DWI SANTOSO \\ Peneliti Pusat Teknologi Lingkungan, BPPT \\ Gedung 820 Geostek, Kawasan Puspiptek Serpong, Tangerang Selatan \\ arif.dwi@bppt.go.id
}

\begin{abstract}
The increase in greenhouse gas (GHG) concentrations in the Earth's atmosphere is largely due to carbon dioxide (CO2) gases, including the carbon dioxide gas emissions resulting from individual human activities over time called carbon footprints. In this study personal carbon footprints were calculated from a variety of potential individual activities resulting in emissions of stafs working at Government Agencies in the Puspiptek area of South Tangerang. The carbon footprint of 35 staffs in Puspiptek area Tangerang Selatan were calculated based on factor emission calculations that have been adapted from reliable sources. Carbon footprint calculations are designed and evaluated based on 5 potentially emitting activities: transportation, foods consumption, energy consumption due to the electrical appliances using, entertains and other activities. The investigation data were analyzed based on gender differences, income level and education level of all respondents. The results stated that staff regularly emit carbon gas of 3.1-6.6 (4.96 \pm 1.23$)$ tons of $\mathrm{CO}_{2}-\mathrm{e} / \mathrm{person} / \mathrm{year}$. The distribution of carbon emissions generated for transport activities of $2.3 \pm 0.78$ tons $\mathrm{CO}_{2}$-e/person/ year, food consumption of $1.35 \pm 0.27$ tons $\mathrm{CO}_{2}$ e/person/year, entertainment 0.34 $\pm 0,13$ tons $\mathrm{CO}_{2}$-e / person / year, garbage $0.29 \pm 0.05$ tons $\mathrm{CO}_{2}$ e/person/year and other purposes $0.39 \pm 0.02$ tons $\mathrm{CO}_{2}-\mathrm{e} /$ person/year. The results showed that there is no significant difference between carbon emissions issued by male and female staff. Male staff emits carbon gas of 4.965 tons $\mathrm{CO}_{2}$-e/person/year while female staffs were 4,923 tons $\mathrm{CO}_{2}$-e/person/year. The high activity represented by staff with higher levels of education increases emissions. Similarly, the higher staff salaries affect the high carbon emissions significantly.
\end{abstract}

Keywords: Global warming, greenhouse gasses, carbon, carbon footprint, government employee

\begin{abstract}
ABSTRAK
Peningkatan konsentrasi gas rumah kaca (GRK) di atmosfir bumi sebagian besar disebabkan oleh gas karbon dioksida $\left(\mathrm{CO}_{2}\right)$, termasuk didalamnya adalah emisi gas karbondiosida yang dihasilkan dari aktivitas individu manusia dalam waktu tertentu yang disebut jejak karbon atau carbon footprint. Dalam penelitian ini jejak karbon individu dihitung dari berbagai aktivitas individu yang berpotensi menghasilkan emisi terhadap 35 sampel pegawai yang bekerja pada Instansi Pemerintah di kawasan Puspiptek Tangerang Selatan. Perhitungan jejak karbon dilakukan dengan menggunakan perhitungan emisi faktor yang telah diadaptasi dari sumber yang terpercaya. Hasil penelitian menunjukkan bahwa pegawai yang berkantor di kawasan Puspiptek secara rutin mengemisikan gas karbon sebesar 3.1 - 6.6 ton $\mathrm{CO}_{2}-$ e/orang/tahun atau rata-rata 4,96 $\pm 1,23$ ton $\mathrm{CO}$-e/orang/tahun. Emisi karbon terdistribusi untuk aktivitas transportasi sebesar 2,3 $\pm 0,78$ ton $\mathrm{CO} 2$-e/ orang/tahun, konsumsi makanan sebesar sebesar 1,35 $\pm 0,27$ ton $\mathrm{CO}_{2}$-e/orang/tahun, hiburan $0,34 \pm 0,13$ ton $\mathrm{CO}_{2}$-e/ orang/tahun, sampah $0,29 \pm 0,05$ ton $\mathrm{CO}_{2}$ e/orang/tahun dan keperluan lainnya 0,39 $\pm 0,02$ ton $\mathrm{CO}_{2}$-e/orang/tahun. Hasil investigasi menyatakan bahwa tidak ada perbedaan yang signifikan antara emisi karbon yang dikeluarkan oleh pegawai laki-laki dan pegawai perempuan. Pegawai laki-laki mengemisikan gas karbon sebesar 4,965 ton $\mathrm{CO}_{2}-$ e/orang/tahun sedangkan pegawai perempuan sebesar 4,923 ton $\mathrm{CO}$-e/orang/tahun. Tingginya aktivitas kantor yang diwakili oleh pegawai dengan tingkat pendidikan yang lebih tinggi meningkatkan emisi. Demikian pula dengan semakin tinggi gaji pegawai mempengaruhi tingginya emisi karbon secara signifikan.
\end{abstract}

Kata kunci : pemanasan global, gas rumah kaca (GRK), jejak karbon, pegawai Instansi Pemerintah 


\section{PENDAHULUAN}

\subsection{Latar Belakang}

Peningkatan konsentrasi gas rumah kaca (GRK) di atmosfir bumi yang didominasi oleh gas karbon dioksida $\left(\mathrm{CO}_{2}\right)$ menjadi perhatian banyak pihak, baik peneliti, pemerhati lingkungan dan pemegang kekuasaan negara di berbagai negara, termasuk Indonesia. Indonesia dalam pertemuan pada The Conferences of Parties (COP) ke-13 UNCCC berkomintmen untuk menurunkan emisi gas rumah kaca sebesar $26 \%$ dengan usaha sendiri dan sebesar $41 \%$ jika mendapat bantuan internasional pada tahun 2020. Untuk mewujudkan komitmen tersebut, Pemerintah Indonesia telah menyusun rencana aksi nasional penurunan gas rumah kaca yang tercantum dalam Peraturan Presiden Republik Indonesia Nomor 61 tahun 2011 tentang Rencana Aksi Nasional Penurunan Emisi Gas rumah Kaca dan Peraturan Presiden Republik Indonesia Nomor 71 tahun 2011 tentang Penyelenggaraan Inventarisasi Gas Rumah Nasional ${ }^{(1)}$.

Aksi nyata mitigasi dampak pemanasan global yang selama ini telah dilakukan baik secara parsial maupun global lebih mengutamakan pada komponen emitter yang berpotensi besar seperti kehutanan, limbah, industri, dan transportasi $i^{(1,2)}$. Hal ini disebabkan karena secara prosentase sektor-sektor tersebut menyumbang emisi gas rumah kaca(GRK) yang besar, meskipun banyak pengamat dan peneliti menilai bahwa upaya tersebut hanya bergerak dalam tataran sistem manajemen saja, tidak menyentuh masyarakat bawah yang langsung terkena dampak ${ }^{(2)}$.

Dalam konteks GRK sebagai emisi gas buang yang dilepaskan ke udara ambien, penyumbang emisi terbesar dalam gas rumah kaca adalah emisi karbon dioksida $\left(\mathrm{CO}_{2}\right)^{(3)}$. Setiap individu dalam aktivitasnya sehari-hari seperti kegiatan konsumsi, berkendaraan, berolah raga, rekreasi akan menghasilkan emisi karbon dioksida $\left(\mathrm{CO}_{2}\right)$, karena sebagain besar aktivitas individu tersebut membutuhkan sumber energi yang berasal dari bahan bakar fosil seperti: minyak bumi, gas alam dan batubara, dan ekstraksi sumber daya alam lainnya ${ }^{(4)}$.

Semakin banyak dan beragam aktivitas manusia, maka semakin banyak emisi karbon yang dibuang ke lingkungan. Besarnya akumulasi emisi karbon akibat aktivitas manusia dalam waktu tertentu disebut jejak karbon atau carbon footprint $t^{(5,6)}$. Jejak karbon sering dijadikan acuan untuk mengukur berapa banyak emisi GRK yang dihasilkan oleh suatu aktivitas atau oleh suatu proses produksi barang atau jasa ${ }^{(7)}$.
Jejak karbon didifinisikaan sebagai suatu ukuran dari aktivitas manusia yang menimbulkan dampak terhadap lingkungan, yang diukur dari berapa banyak emisi karbon (by product) yang berdampak pada kenaikan GRK, biasanya dihitung dalam ukuran unit ton $\mathrm{CO}_{2}{ }^{(8,9)}$. Semua aktivitas seperti konsumsi energi listrik (penggunaan lampu, penggunaan peralatan dapur, alat cukur, penggunaan perangkat elektronik), sampah harian (sampah organik, kertas HVS, botol air minum dalam kemasan (AMDK) dan penggunaan alat transportasi (kendaraan bermotor dan mobil) dapat menghasilkan karbon dioksida $\left(\mathrm{CO}_{2}\right)^{(7,10)}$.

Berdasarkan uraian di atas, dapat dikatakan bahwa peningkatan jejak karbon sebagai dampak dari aktivitas individu manusia sangat signifikan pengaruhnya terhadap peningkatan GRK. Oleh karena itu pemulihan lingkungan hidup tidak dapat mengabaikan aktivitas individu manusia sebagai penyumbang jejak karbon .

Untuk mengetahui berapa besar sumbangan jejak karbon individu ini terhadap peningkatan GRK dan upaya-upaya apa yang dapat dilakukan untuk pemulihan lingkungan hidup, diperlukan penelitian yang lebih mendalam.

Melalui penelitian ini, diharapkan dapat dihitung jejak karbon individu orang Indonesia dan dapat diberikan pemahaman kepada individu-individu agar secara sadar berpartisipasi membatasi jejak karbon yang dihasilkannya. Memperhatikan hal tersebut, maka upaya untuk mengkaji kontribusi individu terhadap carbon footprint yang dihasilkan dari kegiatan manusia sehari-hari menjadi sangat penting.

\subsection{Tujuan Penelitian}

Tujuan dari penelitian ini adalah untuk mengetahui jejak karbon individu pegawai instansi pemerintahan dari berbagai kriteria, yaitu perbedaan gender, tingkat pendidikan dan pendapatan.

Hasil penelitian ini diharapkan dapat menjadi bahan pertimbangan bagi semua pihak sebagai upaya penurunan jumlah GRK serta dapat menjadi informasi atau bahan rujukan alternatif untuk mitigasi bencana pemanasan global di Indonesia.

\section{BAHAN DAN METODE}

\subsection{Bahan}

Penelitian ini dilakukan menggunakan pendekatan kuantitatif dengan mengembangkan konsep yang sudah ada tentang perhitungan jejak karbon individu ${ }^{(11)}$ agar dapat berkontribusi pada pembangunan rendah karbon di Indonesia. 
Penelitian dilakukan pada bulan April-Juni 2017, dengan mengambil sampel sebanyak 35 pegawai yang bekerja di instansi Pemerintah di dalam Kawasan Puspiptek Tangerang Selatan Banten. . Sampel diambil secara acak metode quota sampel yakni dengan cara menyeleksi calon sampel yang sesuai dengan kriteria penelitian terlebih dahulu untuk mendapatkan data dengan komposisi yang lengkap ${ }^{(12)}$. Kreteria data yang ditetapkan adalah keseimbangan porsi data antara jenis kelamin responden (laki-laki dan perempuan), tingkat pendidikan (S-0, S-1, S-2 dan S-3), dan tingkat pendapatan perbulan (kurang dari 5, 5-10,1015 , lebih dari 15) juta rupiah.

Berdasarkan kreteria pemilihan sampel di atas, didapatkan komposisi data seperti dalam tabel 1 di bawah ini.

Tabel 1. Komposisi data penelitian

\begin{tabular}{ccc}
\hline \multirow{2}{*}{ Kreteria } & $\begin{array}{c}\text { Sub- } \\
\text { kreteria }\end{array}$ & $\begin{array}{c}\text { Jumlah } \\
\text { (orang) }\end{array}$ \\
\hline Jenis Kelamin & Laki-laki & 19 \\
\cline { 2 - 3 } & Perempuan & 16 \\
\hline Pendidikan & S-0 & 8 \\
\cline { 2 - 3 } & S-1 & 7 \\
\cline { 2 - 3 } & S-2 & 14 \\
\cline { 2 - 3 } & S-3 & 6 \\
\hline Pendapatan & $<5$ Juta & 8 \\
\cline { 2 - 3 } & 5 -10 Juta & 9 \\
\cline { 2 - 3 } & 10 -15 Juta & 9 \\
\cline { 2 - 3 } & $>15$ Juta & 9
\end{tabular}

\subsection{Metode}

Data jejak karbon dari responden dikumpulkan dengan metode kuesioner. Penggalian data difokuskan pada 5 kegiatan yang berpotensi menghasilkan emisi secara signifikan yaitu kegiatan transportasi, konsumsi makanan, konsumsi energi akibat penggunaan peralatan listrik, produksi sampah dan kegiatan lainnya.

Gambaran tentang format dari kuesioner yang digunakan dalam penelitian di ditampilkan dalam tabel 2 di bawah ini.
Tabel 2. Data aktifitas yang ditampilkan dalam kuesioner

\begin{tabular}{|c|c|c|}
\hline Aktifitas & Sub-kriteria & Keterangan \\
\hline \multirow[t]{3}{*}{ Umum } & Kode & $\begin{array}{l}\text { Diisi oleh } \\
\text { peneliti }\end{array}$ \\
\hline & Nama & Isian optional \\
\hline & $\begin{array}{l}\text { Jenis kelamin, } \\
\text { pendapatan, } \\
\text { pendidikan }\end{array}$ & Isian pilihan \\
\hline \multirow[t]{8}{*}{ Transportasi } & Km motor & \multirow{6}{*}{$\begin{array}{l}\text { Km yang } \\
\text { ditempuh } \\
\text { responden } \\
\text { dengan moda } \\
\text { transportasi } \\
\text { tertentu } \\
\text { selama } 1 \text { tahun }\end{array}$} \\
\hline & Km mobil pribadi & \\
\hline & $\mathrm{Km}$ bus kantor & \\
\hline & Km bus jarak jauh & \\
\hline & $\begin{array}{l}\text { Kali Kereta } \\
\text { komuter }\end{array}$ & \\
\hline & $\begin{array}{l}\text { Kali Kereta jarak } \\
\text { jauh }\end{array}$ & \\
\hline & $\begin{array}{l}\text { Kali pesawat } \\
\text { domestik }\end{array}$ & \multirow{2}{*}{$\begin{array}{l}\text { Frekuensi } \\
\text { penerbangan } \\
\text { selama } 1 \text { tahun }\end{array}$} \\
\hline & Kali pesawat LN & \\
\hline Makanan & $\begin{array}{l}\text { Konsumsi } \\
\text { nasi/karbohidrat, } \\
\text { daging, sayuran, } \\
\text { buah, makanan } \\
\text { cemilan }\end{array}$ & $\begin{array}{l}\text { Frekuensi } \\
\text { konsumsi } \\
\text { selama } 1 \text { tahun }\end{array}$ \\
\hline Listrik & $\begin{array}{l}\text { Pemakaian } \\
\text { peralatan listrik } \\
\text { seperti PC, } \\
\text { Laptop, HP, dan } \\
\text { peralatan pribadi } \\
\text { lainnya. }\end{array}$ & $\begin{array}{l}\text { Isian besaran } \\
\text { daya listrik } \\
\text { (watt), durasi } \\
\text { pemakaian dan } \\
\text { jumlah alat } \\
\text { yang dipakai } \\
\text { selama } 1 \text { tahun }\end{array}$ \\
\hline Sampah & $\begin{array}{l}\text { Kg sampah } \\
\text { organik Lembar } \\
\text { sampah kertas }\end{array}$ & $\begin{array}{l}\text { Akumulasi } \\
\text { sampah } \\
\text { selama } 1 \text { tahun }\end{array}$ \\
\hline Hiburan & $\begin{array}{l}\text { Aktifitas berenang } \\
\text { Menginap di hotel } \\
\text { Ke tempat } \\
\text { rekreasi } \\
\text { Ke bioskop }\end{array}$ & $\begin{array}{l}\text { Frekuensi } \\
\text { kegiatan } \\
\text { selama } 1 \text { tahun }\end{array}$ \\
\hline Lainnya & $\begin{array}{l}\text { Penggunaan } \\
\text { peralatan } \\
\text { bersama seperti: } \\
\text { AC, Dispenser, } \\
\text { Lampu, TV } \\
\text { Rice cooker, dll. }\end{array}$ & $\begin{array}{l}\text { Isian besaran } \\
\text { daya listrik } \\
\text { (watt), durasi } \\
\text { pemakaian dan } \\
\text { jumlah alat } \\
\text { yang dipakai } \\
\text { selama } 1 \text { tahun } \\
\text { dibagi dengan } \\
\text { jumlah } \\
\text { pemakai }\end{array}$ \\
\hline
\end{tabular}

\subsection{Pengolahan Data}

Data aktivitas responden yang telah diperoleh dikelompokkan berdasarkan kreteria yang ditetapkan dan dihitung menggunakan persamaan 1 di bawah ini ${ }^{(13,14)}$.

$\mathrm{PCF}\left(\right.$ ton $\left.\mathrm{CO}_{2}-\mathrm{e}\right)=$ 
$\Sigma$ (pemakaian kom. 1 tahun) $\times$ EF....(1)

Kemudian, untuk menampung komposisi komoditas penelitian ini, maka persamaan diadaptasikan menjadi :

PCF (ton $\left.\mathrm{CO}_{2}-\mathrm{e}\right)=$

$\Sigma\left(\mathrm{kom}_{1} \times \mathrm{EF}_{1}\right)+\left(\mathrm{kom}_{2} \times \mathrm{EF}_{2}\right)+\ldots$

$\left(\right.$ kom $\left._{\mathrm{n}} \times E F_{\mathrm{n}}\right)$

Keterangan

PCF : Personal Carbon Footprint

$\mathrm{CO}_{2}$-e : $\mathrm{CO}_{2}$ equivalen/setara

EF : Emission Factor

Kom : komoditas

Data emisi faktor (EF) dikumpulkan dan dianalisis dari sumber literatur yang terpercaya Sebagaimana disajikan dalam tabel 3 di bawah ini.

Tabel 3. Daftar nilai EF yang digunakan dalam penelitian

\begin{tabular}{ccl}
\hline No & \multicolumn{1}{c}{ Komoditas (satuan) } & Nilai EF \\
\hline 1. & Listrik $\left(\mathrm{kg} \mathrm{CO}_{2}-\mathrm{e} / \mathrm{kWh}\right)$ & $0.62142^{(15)}$ \\
2. & Motor/mobil $\left(\mathrm{kg} \mathrm{CO}_{2}-\mathrm{e} / \mathrm{km}\right)$ & $0.2310^{(16)}$ \\
3. & Bus kantor $\left(\mathrm{kg} \mathrm{CO}_{2}-\mathrm{e} / \mathrm{km}\right)$ & $0.03417^{(15)}$
\end{tabular}

\begin{tabular}{|c|c|c|}
\hline & Bus jarak jauh $\left(\mathrm{kgCO}_{2}-\mathrm{e} / \mathrm{km}\right)$ & $0.086^{(15)}$ \\
\hline & Kereta krl (kg CO$\left.{ }_{2}-\mathrm{e} / \mathrm{km}\right)$ & $0.1056^{(2)}$ \\
\hline & Kereta malam ( $\left.\mathrm{kg} \mathrm{CO}_{2}-\mathrm{e} / \mathrm{km}\right)$ & $0.08^{(16)}$ \\
\hline & $\begin{array}{l}\text { Pesawat domestik }\left(\mathrm{kg} \mathrm{CO}_{2^{-}}\right. \\
\mathrm{e} / \mathrm{km})\end{array}$ & $0.41^{(15)}$ \\
\hline & Pesawat LN (kg CO$\left.{ }_{2}-\mathrm{e} / \mathrm{km}\right)$ & $0.26^{(15)}$ \\
\hline & Karbohidrat $\left(\mathrm{kg} \mathrm{CO}_{2}-\mathrm{e} / \mathrm{kg}\right)$ & $3.9^{(17)}$ \\
\hline & Daging $(\mathrm{kg} \mathrm{CO}-\mathrm{e} / \mathrm{kg})$ & $35.9^{(17)}$ \\
\hline & Ikan $(\mathrm{kg} \mathrm{CO}-\mathrm{e} / \mathrm{kg})$ & $5.4^{(17)}$ \\
\hline & Sayuran $(\mathrm{kg} \mathrm{CO}-\mathrm{e} / \mathrm{kg})$ & $1.6^{(17)}$ \\
\hline & Buah $\left(\mathrm{kg} \mathrm{CO}{ }_{2}-\mathrm{e} / \mathrm{kg}\right)$ & $0.9^{(17)}$ \\
\hline & Telur $\left(\mathrm{kg} \mathrm{CO}{ }_{2}-\mathrm{e} / \mathrm{kg}\right)$ & $4.9^{(17)}$ \\
\hline & $\begin{array}{l}\text { Menginap di hotel }\left(\mathrm{kg} \mathrm{CO} \mathrm{CO}^{-}\right. \\
\text {e/malam) }\end{array}$ & $15.13^{(18)}$ \\
\hline & $\begin{array}{l}\text { Sampah organik }\left(\mathrm{kg} \mathrm{CO}_{2^{-}}\right. \\
\text {e/kg) }\end{array}$ & $0.374^{(19)}$ \\
\hline & $\begin{array}{l}\text { Sampah kertas }\left(\mathrm{kg} \mathrm{CO}_{2} \text {-e/100 }\right. \\
\text { lembar) }\end{array}$ & $0.963^{(19)}$ \\
\hline
\end{tabular}

\footnotetext{
Sumber:

US EPA, $2010^{(15)}$

US DOE, $2010^{(16)}$

Scarborough, et al., 2014 ${ }^{(15)}$

Roy et al., $2009^{(10}$

Wilson R., $2013^{(19)}$
}

\section{HASIL DAN PEMBAHASAN}

\subsection{Jejak Karbon Secara Umum}

Perhitungan jejak karbon terhadap 35 pegawai instansi pemerintah di kawasan Puspiptek disampaikan dalam Gambar 1.

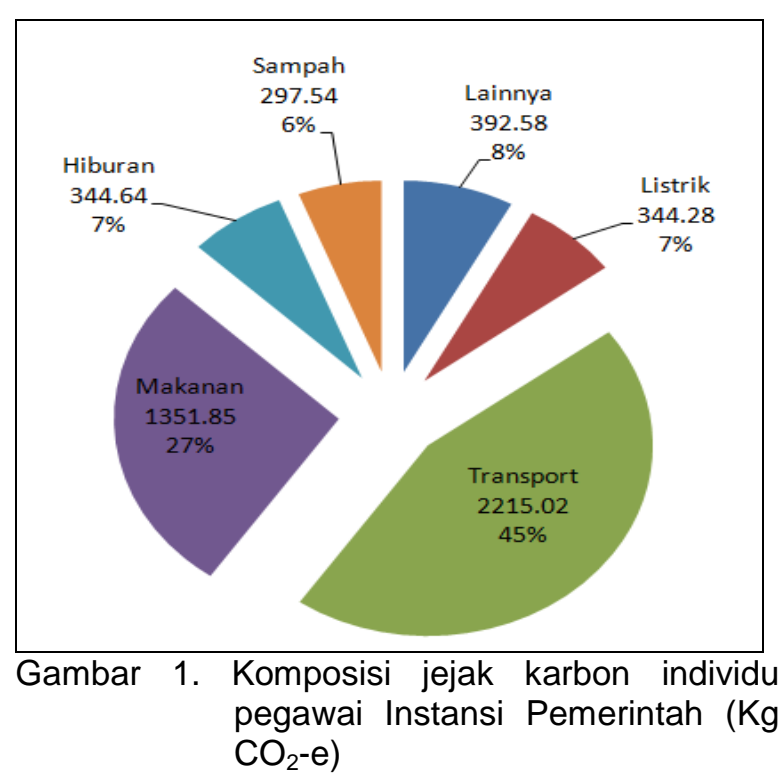

Hasil perhitungan menunjukkan bahwa pegawai yang berkantor di kawasan Puspiptek secara rutin menghasilkan emisi gas karbon antara 3,1 - 6,6 ton $\mathrm{CO}_{2}$-e/orang/tahun atau rata-rata 4,96 $\pm 1,23$ ton $\mathrm{CO}_{2}$-e/orang/tahun. secara lebih rinci, emisi karbon yang dihasilkan dari setiap aktivitas pegawai adalah : transportasi sebesar 2,3 $\pm 0,78$ ton $\mathrm{CO}_{2}-\mathrm{e} /$ orang/tahun, konsumsi makanan sebesar sebesar 1,35 $\pm 0,27$ ton $\mathrm{CO}_{2}$-e/ orang/tahun, hiburan $0,34 \pm 0,13$ ton $\mathrm{CO}_{2}$-e/tahun, sampah $0,29 \pm 0,05$ ton $\mathrm{CO}_{2}$-e/orang/tahun dan keperluan lainnya $0,39 \pm 0,02$ ton $\mathrm{CO}_{2}$ e/orang/tahun.

Jejak karbon akibat aktivitas transportasi menempati urutan teratas dengan emisi sebesar 2,3 ton $\mathrm{CO}_{2}$-e/orang/tahun atau sekitar $45 \%$ dari rata-rata total emisi seorang pegawai. Tingginya emisi dari aktivitas transportasi ini dimungkinkan karena banyaknya kegiatan perjalanan dinas maupun pribadi dengan mengunakan pesawat terutama bagi responden dengan tingkat pendidikan yang tinggi. Beberapa responden yang mengunakan mobil pribadi saat pergi ke kantor juga ikut meningkatkan emisi di sektor ini. Selain itu jarak rumah beberapa responden dan kantor yang relatif jauh $( \pm 50 \mathrm{~km})$, juga memicu peningkatan emisi meskipun mereka menggunakan bus kantor atau angkutan umum.

Hasil penelitian jejak karbon individu ini sedikit berbeda dengan hasil penelitian beberapa peneliti sebelumnya. Utaraskul(20) menyatakan bahwa emisi yang dihasilkan dari 
kegiatan transportasi mahasiswa Sun Sunandha Rajabhat Universitai (RSSU) Thailand sekitar 0,4 ton $\mathrm{CO}_{2}$-e/orang/tahun atau sekitar $15 \%$ dari emisi total. Hasil penelitiannya menunjukkan bahwa mayoritas responden/ mahasiswa bertempat tinggal di kampus dan menggunakan sepeda kayuh. Transportasi dilakukan hanya untuk keperluan ke luar kota untuk acara sekolah dan kegiatan rekreasi. Penelitian lain dilakukan oleh Shirley ${ }^{(14)}$ pada komunitas perumahan di Virgin Island US. Hasil penelitiannya menyatakan bahwa aktivitas trasportasi menyumbag emisi sebesar 3,12 ton $(25 \%)$ dari rata rata emisi perumahan sebesar 13 ton $\mathrm{CO}_{2}$-e/orang/tahun

\subsection{Komposisi Jejak Karbon Berdasarkan Jenis Kelamin}

Hasil perhitungan jejak karbon dari 35 responden dengan komposisi 19 laki-laki dan 16 perempuan disajikan dalam Tabel 4 di bawah ini.

Tabel 4. Hasil perhitungan jejak karbon dari pegawai berdasarkan jenis kelamin

\begin{tabular}{llrr}
\hline Katagori & $\begin{array}{c}\text { Jenis } \\
\text { Kelamin }\end{array}$ & $\begin{array}{c}\text { Min } \\
\text { (kg CO2-e) }\end{array}$ & $\begin{array}{c}\text { Max } \\
(\mathrm{kg} \mathrm{CO2-} \\
\mathrm{e})\end{array}$ \\
\hline Listrik & Laki-laki & 268,00 & 399,56 \\
\multirow{2}{*}{ Transportasi } & Perempuan & 286,00 & 399,07 \\
& Laki-laki & $1.084,00$ & $3.199,89$ \\
Makanan & Perempuan & $1.043,00$ & $3.024,59$ \\
& Laki-laki & 958,00 & $1.711,14$ \\
Hiburan & Perempuan & $1.149,76$ & $1.937,03$ \\
& Laki-laki & 151,00 & 484,04 \\
Sampah & Perempuan & 147,00 & 488,61 \\
& Laki-laki & 229,00 & 405,88 \\
Lainnya & Perempuan & 231,00 & 421,46 \\
& Laki-laki & 358,00 & 419,63 \\
Semua & Perempuan & 354,00 & 413,43 \\
Kategori & Laki-laki & $3.101,12$ & $6.581,48$ \\
& Perempuan & $3.316,03$ & $6.585,84$ \\
& Semua & $3.101,12$ & $6.585,84$ \\
\hline
\end{tabular}

Nilai emisi minimum dan maksimum jejak karbon pegawai laki-laki maupun perempuan dari semua katagori menunjukkan nilai yang hampir sama. Namun bila dianalisis dengan menghitung emisi rata-ratanya pada setiap katagori akan terlihat adanya beberapa perbedaan meskipun perbedaannya relatif kecil.

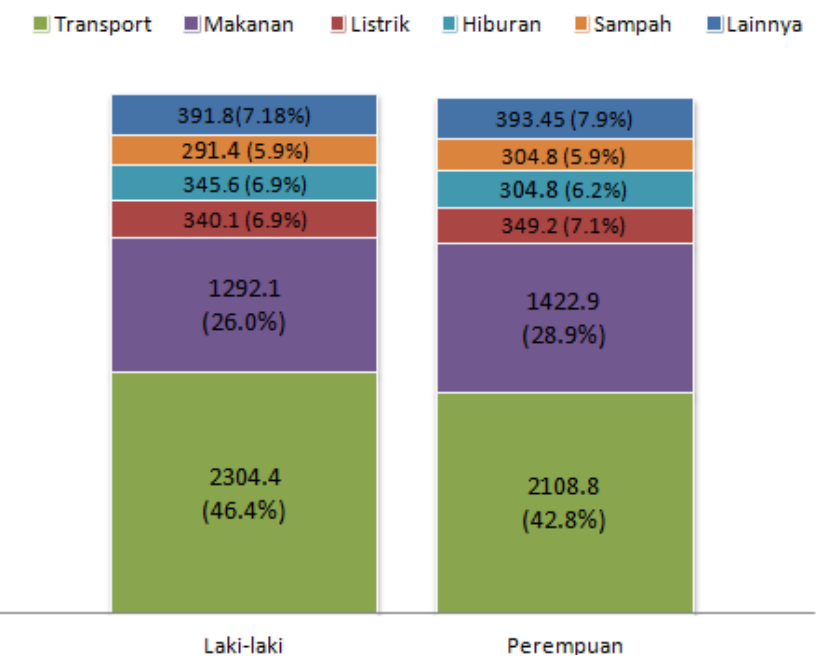

Gambar 2. Nilai rata-rata jejak karbon responden laki-laki dan perempuan berdasarakan setiap katagori

Dari data nilai rata-rata jejak karbon (gambar 2) dapat diindentifikasi perbedaan emisi $\mathrm{CO}_{2}$ antara pegawai laki-laki dan perempuran. Emisi rata-rata pada aktivitas transportasi pegawai laki-laki lebih tinggi daripada pegawai perempuan yakni sekitar 2,23 ton $\mathrm{CO}_{2}$-e/orang/tahun sedangkan pegawai wanita hanya 2,1 ton $\mathrm{CO}_{2}$-e/orang/tahun.

Sebaliknya pada aktifitas konsumsi makanan, pegawai perempuan menghasilkan emisi karbon sekitar 1,42 ton $\mathrm{CO}_{2}$-e/orang/tahun lebih tinggi dibanding pegawai laki-laki yaitu sebesar 1,29 ton $\mathrm{CO}_{2}$-e/orang/tahun. Jejak karbon dari aktifitas penggunaan listrik, aktifitas hiburan dan aktivitas lainnya relatif sama antara pegawai laki-laki dan perempuan.

Tingginya emisi karbon pegawai laki-laki pada aktivitas transportasi dimungkinkan karena peluang pegawai laki-laki untuk melakukan perjalanan dinas atau perjalanan pribadi relatif besar. Hal ini dikarenakan beberapa alasan antara lain kesesuaian tugas dinas/luar kota yang lebih berpihak pada pegawai laki-laki. Beberapa tugas yang memiliki resiko seperti kemalaman di jalan, lamanya penugasan ke luar kota, terbatasnya personil yang pergi, lebih sering dibebankan ke pegawai laki-laki.

Pada aktivitas konsumsi makanan, pegawai perempuan memiliki kemampuan untuk memilih dan menentukan variasi makanan dan minuman yang lebih banyak sehingga menghasilkan emisi yang lebih tinggi di banding pegawai laki-laki. Tingginya emisi karbon dalam aktivitas konsumsi makanan dan minuman yang dihasilkan oleh pegawai perempuan dibanding pegawai laki-laki sejalan dengan penelitiannya $^{(14)}$. 


\subsection{Komposisi Jejak Karbon Berdasarkan Pendidikan dan Pendapatan}

Perhitungan jejak karbon pegawai berdasarkan tingkat pendidikan dan pendapatan yang diterima tiap bulan disajikan pada gambar 3 dan gambar 4.

Nilai jejak karbon pegawai berdasarkan tingkat pendidikan dan pendapan menunjukkan pola yang hampir sama. Nilai jejak karbon meningkat seiring dengan peningkatan tingkat pendidikan dan pendapatan yang mereka diterima. Nilai jejak karbon pegawai berpendidikan dan berpendapatan lebih tinggipada aktivitas transportasi dan konsumsi makanan mengalami kenaikan yang relatif besar sedangkan aktivitas lain juga mengalami peningkatan meskipun kecil. Jejak karbon pada aktifitas transportasi juga mengalami kenaikan yang relatif tinggi sejalan dengan tingkat pendidikannya. Jejak karbon pegawai berpendidikan S-0, S-1, S-2 dam S-3 secara berturut turut adalah 1,$24 ; 1,85 ; 2,65$ dan 2,92 ton $\mathrm{CO}_{2}$-e/orang/tahun atau meningkat sekitar $42,5 \%$.

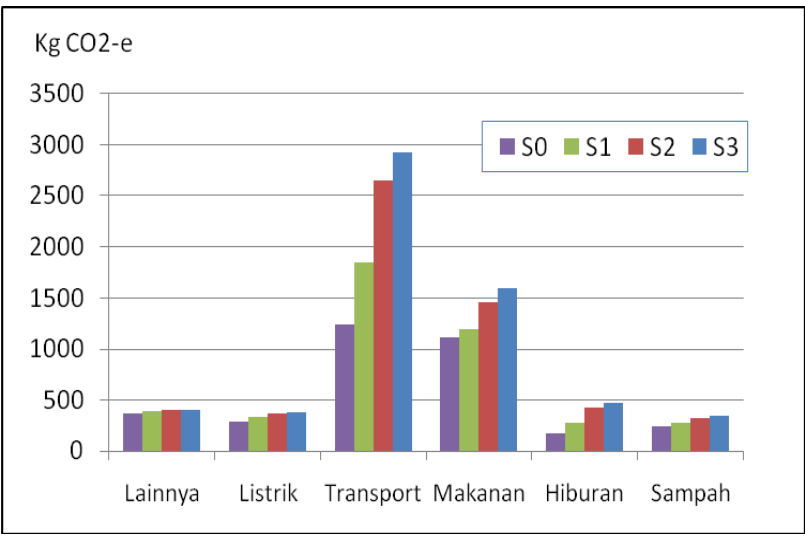

Gambar 3. Nilai rata-rata jejak karbon berdasarkan tingkat pendidikan

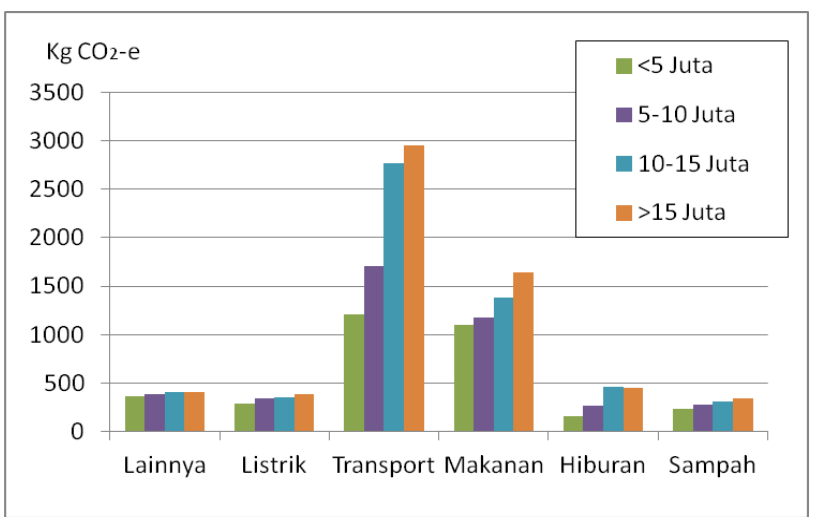

\section{Gambar 4. Nilai rata-rata jejak karbon berdasarkan pendapatan bulanan}

Sementara itu seiring dengan peningkatan pendapatan pegawai jumlah emisi akibat aktifitas transportasi juga mengalami peningkatan sekitar $40,8 \%$. Pada katagori lain, jejak karbon pada aktifitas konsumsi makanan juga mengalami kenaikan yang relatif tinggi. Nilai jejak karbon mulai dari pegawai berpendidikan S-0, S-1, S-2 dam S-3 berturut turut 1,$11 ; 1,18 ; 1,46$ dan 1,60 ton $\mathrm{CO}_{2}$ e/orang/tahun atau meningkat sekitar $69,8 \%$, sementara seiring peningkatan emisi karena aktifitas konsumsi makanan juga meningkat sekitar $66,89 \%$.

Kesamaan pola kenaikan jejak karbon ini dimungkinkan karena ada korelasi yang kuat antara tingkat pendidikan dan tingkat pendapatan yang berujung pada meningkatnya mobilitas kerja dan pola konsumsi pegawai. Pegawai dengan tingkat pendidikan yang lebih tinggi akan berpeluang untuk melaksanakan tugas-tugas yang lebih banyak dan berkualitas dibanding dengan pegawai biasa. Kondisi pada pegawai yang aktif tersebut akan berpeluang dapat meningkatkan pendapatannya. Dengan pendapatan yang meningkat tersebut pegawai akan berpotensi untuk meningkatkan frekuensi aktivitas perjalanan dan konsumsi makanannya yang berimbas pada kenaikan jejak karbonnya.

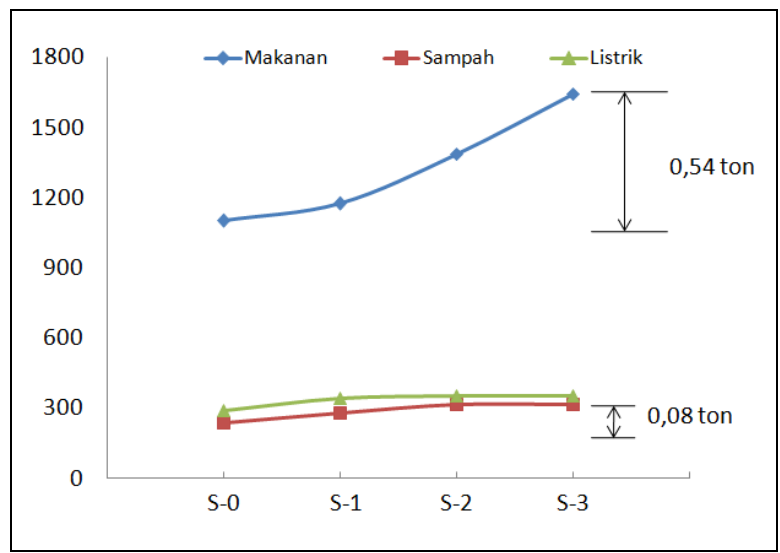

Gambar 5. Hubungan antara peningkatan emisi akibat konsumsi makanan terhadap emisi pemakaian listrik dan sampah

Korelasi hubungan antara tingkat pendidikan dengan nilai jejak karbon pada aktivitas konsumsi yang berimbas pada aktifitas penggunaan listrik dan sampah yang ditampilkan pada gambar 5 .

Pegawai dengan tingkat pendidikan yang lebih tinggi berpeluang memperoleh pendapatan bulanan yang meningkat. Pendapatan yang meningkat akan meningkatkan pola konsumsi yang ditandai dengan meningkatnya emisi dari aktifitas konsumsi.

Namun demikian, peningkatan belanja konsumsi makanan dan minuman tidak disertai dengan peningkatan emisi dari aktifitas penggunaan listrik dan limbah sampah yang dihasilkan, yang besarnya peningkatan emisi 
masing-masing adalah 0,54 ton $\mathrm{CO}_{2}$-e/orang /tahun dari aktifitas konsumsi dan hanya 0,08 ton $\mathrm{CO}_{2}$-e/orang/tahun dari aktifitas penggunaan listrik dan sampah. Beberapa kemungkinan yang bisa disampaikan untuk menjawab fenomena ini adalah pertama, tingkat pendidikan pegawai akan membentuk dan mempengaruhi pola berfikir dan bertindak menjadi lebih konstruktif dan hemat dalam mengkonsumsi barang/jasa, menggunakan listrik atau lebih mengerti kelestarian lingkunga/alam. Alasan lain adalah dengan peningkatan tingkat pendidikan yang diseiringi dengan peningkatan pendapatan akan lebih memberikan kesempatan yang besar bagi pegawai untuk memilih barang/makanan dengan kondisi yang lebih baik kualitasnya baik dari sisi hemat energi listrik maupun minim menghasilkan sampah.

\section{KESIMPULAN}

Pegawai Instansi Pemerintah yang berkantor di kawasan Puspiptek Tangerang Selatan, secara rutin mengemisikan gas karbon sebesar 3,1-6,6 ton $\mathrm{CO}_{2}$-e/orang/tahun atau rata-rata sebesar $4,96 \pm 1,23)$ ton $\mathrm{CO}_{2^{-}}$ e/orang/tahun. Emisi karbon tersebut terdistribusi akibat aktivitas transportasi sebesar $2,3 \pm 0,78$ ton $\mathrm{CO}_{2}$-e/ orang/tahun, konsumsi makanan sebesar sebesar $1,35 \pm 0,27$ ton $\mathrm{CO}_{2}$ e/orang/tahun, hiburan $0,34 \pm 0,13$ ton $\mathrm{CO}_{2}$ e/orang/tahun, sampah $0,29 \pm 0,05$ ton $\mathrm{CO}_{2}{ }^{-}$ e/orang/tahun dan keperluan lainnya 0,39 $\pm 0,02$ ton $\mathrm{CO}_{2}$-e/orang/ tahun.

Nilai jejak karbon pegawai laki-laki dan pegawai perempuan menunjukkan nilai yang hampir sama. Pegawai laki-laki dominan mengemisikan gas $\mathrm{CO}_{2}$ pada aktifitas perjalanan, sedangkan pegawai perempuan dominan pada kegiatan konsumsi makanan. Nilai jejak karbon pegawai berdasarkan tingkat pendidikan dan pendapatan menunjukkan pola yang hampir sama, yakni meningkat seiring dengan peningkatan tingkat pendidikan dan pendapatan yang mereka diterima.

Tingkat pendidikan pegawai mempengaruhi pola berfikir dan bertindak pegawai menjadi lebih konstruktif dan hemat dalam mengkonsumsi barang/jasa, menggunakan listrik atau peka terhadap pentingnya menjaga kelestarian lingkunga/alam.

\section{PERSANTUNAN}

Penulis menyampaikan terima kasih kepada Kementerian Riset Teknologi dan Pendidikan Tinggi RI atas dukungan pembiayaan penelitian ini melalui Program Insinas 2017. Penghargaan yang tinggi penulis sampaikan kepada Prof. Dr. Kardono, M.Eng dan Dr. Joko Prayitno Susanto,
M.Eng atas bantuan telaah dan diskusi selama penulisan naskah. Ucapan terima kasih juga penulis sampaikan kepada Dr. Nawa Suwedi, M.Sc., dan Dr. Joko Prayitno, M.Sc dan lif Miftahul Ihsan, S.Si sebagai anggota tim penelitian yang telah memberikan bantuan penelusuran literatur dan diskusi demi tersusunnya makalah ini.

\section{DAFTAR PUSTAKA}

1. Anonim, (2012), Buku Referensi Pedoman Pelaksanaan Rencana Aksi Penurunan Emisi Gas rumah kaca, Kementerian Perencanaan Pembangunan Nasional/ Badan Perencaaan Pembangunan Nasional, Jakarta

2. Saragih H., (2009), Pemerintah Indonesia tidak serius mengatasi perubahan iklim diunduh dari http://www.spi.or.id/pemerintahindonesia-tidak-serius-mengatasiperubahan-iklim/ (dilihat 14 April 2017).

3. Eggleston, S., Leandro B., Kyoko M., Todd N., dan Tanabe K., (2006), Intergovernmental Panel on Climate Change (IPCC) Guidelines for National Green House Gas Inventories. Published by the Institute for Global Environmental Strategies (IGES), Hayama, Japan

4. Anonim, (2016), Handbook of Energy \& Economic Statistics of Indonesia (Final ed.), Departemen Energi dan Sumber Daya Mineral, Pusat Data dan Informasi Sumber Daya Mineral dan Energi, ESDM Press, Jakarta.

5. Rahayu, M. (2011), Hutang Karbon dan Isu Pemanasan Global. Diunduh dari http://www.kabarindonesia.com/berita.php?p il=4\&jd=Hutang+Karbon+dan+lsu+Pemanas an+Global\&dn=20110613051316 (dilihat 14 April 2017).

6. Armel, M., Diah, R., dan Moekti H.S., (2004), Bumi makin panas ancaman perubahan iklim di Indonesia, Kementerian Lingkungan Hidup.Jakarta.

7. Astari, R. G., (2012), Studi Jejak Karbon Dari Aktivitas Permukiman Di Kecamatan Pademangan Kotamadya Jakarta Utara. Depok: Fakultas Teknik, Program Studi Teknik Lingkungan, Universitas Indonesia.

8. Anonim, (2007), Ecological Footprint: Overview, Global Footprint Network, available from http://www.footprintnetwork.org/gfn_sub.php ?content=footprint_overview (viewed March $3,2017)$ 
9. Padgett, JP, A.C. Steinemann, J.H. Clarke, \& M.P. Vandenbergh, (2008), A comparison of carbon calculators, Environmental Impact Assessment Review, 28: 106-115.

10. Anonim, (2011), Kalkulator jejak karbon, Institute for Essential Services Reforms (IESR), available from http://karbonkalkulator.iesrindonesia.org/index.php/member/home (viewed March 10, 2017).

11. Sumanto. M.A. , (1995), Metodologi Penelitian Sosial Dan Pendidikan, Yogyakarta : Andi Offset.

12. Dodge, Y. (2003), The Oxford Dictionary of Statistical Terms, OUP. Oxford University Press Inc., New York.

13. Anonim, (2010), household calculator, University of California, aviable at http://coolclimate.berkeley.edu.usvi_calc (viewed February 20, 2017).

14. Shirley R., C. Jones, D. Kammen, (2012), A household carbon footprint calculator for islands: Case study of the United States Virgin Islands, Ecological Economics, 80:814.

15. Anonim, (2010), Calculator in excel, United States Environmental Protection Agency, available http://www.epa.gov/climatechange/emission s/ ind_calculator.html (viewed March 11, 2017).

16. Anonim, (2010), Carbon footprint calculator, United States Department of Energy, available from https://energy.gov/eere/sunshot/downloads/c arbon-footprint-calculator (viewed March 11, 2017).

17. Scarborough P., P.N. Appleby, A. Mizdrak, A.D.M. Sbriggs, R.C. Travis, K.E. Bradbury, \& J.K. Timothy, (2014), Dietary greenhouse gas emissions of meat-eaters, fish-eaters, vegetarians and vegans in the UK, Climatic Change, 125:179-192.

18. Roy P, D. Nei, T. Orikasa, Q. Xu, H. Okadome, N. Nakamura, T. Shiina, (2009), A review of life cycle assessment (LCA) on some food products. J Food Eng, 90(1):110.

19. Wilson R., (2013), Carbon Counter available from http://www.carboncounter.org/(viewed May 11, 2017).

20. Utaraskul T., (2015), Carbon Footprint of Environmental Sciences Students in Suan Sunandha Rajabhat university, Thailand, Procedia-Social and Behavioral Sciences, 197: 1156-1160. 